\title{
Critical evaluation of the nursery role hypothesis for seagrass meadows
}

\author{
K. L. Heck Jr. ${ }^{1, *}$, G. Hays ${ }^{2}$, R. J. Orth ${ }^{3}$ \\ ${ }^{1}$ Dauphin Island Sea Lab, University of South Alabama, 101 Bienville Boulevard, Dauphin Island, Alabama 36528, USA \\ ${ }^{2}$ Department of Ecology and Evolutionary Biology, University of California Santa Cruz, 225 Sinsheimer Avenue, Santa Cruz, \\ California 95064, USA \\ ${ }^{3}$ Virginia Institute of Marine Sciences, College of William and Mary, 1208 Greate Road, Gloucester Point, Virginia 23062, USA
}

\begin{abstract}
The vast majority of published papers concerning seagrass meadows contain statements to the effect that seagrass beds serve as important nurseries for many species. We reviewed more than 200 papers that were relevant to the nursery role hypothesis. We used both vote counting and meta-analytic techniques to evaluate whether the body of previous studies that report seagrass meadows to be nursery grounds actually contain data that support this proposition. We restricted our analyses to papers that compared seagrass beds to other habitats, and examined data on a variety of well-studied species concerning their density, growth, survival and migration to adult habitat. Within this group of papers, we considered potential factors that could influence the nursery function (e.g. location, or laboratory vs field studies). We also evaluated case histories of well-documented largescale seagrass losses on the nursery function. Major results were consistent with the expectations that abundance, growth and survival were greater in seagrass than in unstructured habitats. Abundance data also suggested that seagrass beds in the Northern Hemisphere might be more important as nursery areas than those in the Southern Hemisphere. Surprisingly, few significant differences existed in abundance, growth or survival when seagrass meadows were compared to other structured habitats, such as oyster or cobble reefs, or macroalgal beds. Nor were there decreases in harvests of commercially important species that could clearly be attributed to significant seagrass declines in 3 wellstudied areas. However, there were decreased abundances of juveniles of commercially important species in these areas, suggesting a strong link between seagrass abundance and those of juvenile finfish and shellfish. One important implication of these results is that structure per se, rather than the type of structure, appears to be an important determinant of nursery value. Clearly, more rigorous studies that test all aspects of the nursery role hypothesis are clearly needed for seagrass meadows as well as other structured habitats. The results of such studies will allow better decisions to be made concerning the conservation and restoration of marine habitats.
\end{abstract}

KEY WORDS: Nursery role $\cdot$ Seagrass meadows $\cdot$ Meta-analysis

Resale or republication not permitted without written consent of the publisher

\section{INTRODUCTION}

Seagrass meadows occur in shallow coastal waters of most continents (den Hartog 1970). During the past several decades, they have received increasing attention from scientists and natural resource managers because of the valuable functional roles they play in coastal ecosystems (Costanza et al. 1997) and because of the accelerating trend of worldwide seagrass loss (Short \& Wyllie-Echeverria 1996). Valuable functions generally associated with seagrasses and cited frequently in the seagrass literature include nutrient recycling, detrital production and export, sediment stabilization, and provision of optimal habitat for growth, survival and reproduction of a diverse array of vertebrate and invertebrate taxa. One of the more frequently cited measures of seagrass habitat value, and one that is very often argued for its conservation and restoration, is its 'nursery function'. The concept of the seagrass nursery function has been principally derived 
from the numerous studies that report higher densities of juvenile animals in seagrass than in adjacent unvegetated areas (see Orth \& van Montfrans 1987, Heck et al. 1997, Beck et al. 2001 for overviews of the evidence supporting the nursery concept).

The nursery concept, as originally developed, proposed that entire estuaries were nurseries. Subsequently, specific habitats within the estuary came to be referred to as nursery areas because higher abundances of juvenile fish and invertebrates were routinely found in structurally complex habitats, such as marshes, mangroves and seagrasses (Beck et al. 2001). However, the concept of a nursery must extend beyond simply the numbers of juveniles present, but also may entail higher survival, owing to protection from predators, and higher specific growth rates, due to the abundance of food resources within seagrass meadows, both of which are likely to result in more juveniles reaching the adult stage. The pressing need to prioritize areas for preservation and conservation, together with the results of some studies that have failed to find a significant seagrass nursery function for certain species (Heck et al. 1989, Gillanders \& Kingsford 1996, Butler \& Jernakoff 2000), are forcing a re-evaluation of the seagrass nursery concept and its general applicability (Beck et al. 2001).

The goals of this paper are to review and critically evaluate published studies in which seagrass beds are purported to be nurseries. In addition, we sought to identify factors that create spatial variation in the nursery function of seagrass habitats, and to use welldocumented declines of seagrass to address whether loss of seagrass habitat has led to corresponding declines in species believed to use these habitats as nurseries. Here, we use the definition of nursery habitat provided by Beck et al. (2001): 'a habitat is a nursery for juveniles of a particular species if its contribution per unit area to the production of individuals that recruit to adult populations is greater, on average, than production from other habitats in which juveniles occur.' Beck et al. (2001) also argue that 'the ecological processes operating in nursery habitats, when compared to other habitats, must support greater contributions to adult recruitment from any combination of 4 factors: (1) density, (2) growth, (3) survival of juveniles and (4) movement to adult habitats.'

\section{MATERIALS AND METHODS}

Literature search and data selection. We reviewed papers containing information pertinent to the nursery role of seagrasses by both searching Cambridge Scientific Abstracts (CSA) and also our personal libraries in order to include any relevant papers not identified in the CSA search. From the nearly 200 papers identified, we selected only those that fulfilled the following criteria, consistent with our (Beck et al. 2001) definition of a nursery: (1) The study provided data on at least 1 of the 4 variables that could indicate a nursery function for a particular seagrass meadow for a given animal species: juvenile density, growth rate, survivorship and/or success of movement from juvenile to adult habitats (2) The species being studied possesses a 'transient' life history consistent with the nursery role hypothesis (i.e. juvenile and adult habitats do not entirely overlap). Considerable work has been done on the effects of seagrass characteristics (e.g. blade morphology, shoot density) on predation risk for seagrass residents, such as amphipods and grass shrimp (see reviews by Heck \& Crowder 1991, Williams \& Heck 2001). However, these species' life histories make them inappropriate for questions regarding nurseries; thus, papers concerning permanent seagrass residents, including commercially important species, such as bay scallop, were not included in our analysis. Similarly, papers that presented only aggregate data for multiple species (e.g. 'total number of fish per trawl') were not considered, because it is highly likely that the data included seagrass permanent residents as well as potential 'nursery' species. (3) The study examined seagrass habitat and at least one other habitat type (e.g. salt marsh, oyster reef, adjacent unvegetated sediment). While a great many studies of the fauna of seagrass meadows have been carried out, we could not include many of them in our analyses because they did not include comparative data from at least one other type of habitat. Therefore, the number of studies that we used was far less than the number of studies published on the fauna of seagrass meadows.

All the references used in the analyses described below are listed in Table 1.

Data analysis. We used the traditional 'votecounting' approach to examine density of juveniles (e.g. Connell 1983, Schoener 1983, Sih et al. 1985) among habitats because of dissimilarities in sampling methodology, and because it usually was not possible to extract the information necessary for meta-analysis from the existing literature. The data we report are the number of times abundances were reported to be statistically larger or smaller than in other habitats, as well as the number of times when there were no statistically significant differences among habitats. The vote-counting is known to be biased toward finding 'no effect', especially when sample sizes and effects are relatively small (Hedges \& Olkin 1985), and this must be kept in mind when interpreting vote-counting results. It is also an important reason why metaanalysis is the preferred to vote-counting, when permitted by the characteristics of the body of data being analyzed (Gurevitch \& Hedges 2001). 
Table 1. Studies meeting the criteria (as described in the text) that were used in comparisons of density, growth and survival in seagrass meadows and other habitats. A: studies used in the abundance comparisons; S: studies used in survival comparisons; G: studies used in growth comparisons. Some studies were used in more than 1 type of comparison

\begin{tabular}{|c|c|c|c|}
\hline \multicolumn{2}{|c|}{$\begin{array}{l}\text { Type of } \\
\text { comparison }\end{array}$} & \multicolumn{2}{|c|}{$\begin{array}{l}\text { Type of } \\
\text { comparison }\end{array}$} \\
\hline A & Arrivillaga \& Baltz (1999) & $\mathrm{A}$ & McMichael \& Peters (1989) \\
\hline A & Bayer (1981) & A & Morgan et al. (1996), Nagelkerken et al. (2000) \\
\hline A & Bell \& Westoby (1987) & $\mathrm{S}$ & Olmi \& Lipcius (1991) \\
\hline A & Briggs \& O'Connor (1971) & $\mathrm{A}$ & Olney \& Boehlert (1988) \\
\hline A & Connolly (1994a) & $\mathrm{A}$ & Orth \& van Montfrans (1987) \\
\hline A & Connolly (1994b) & $\mathrm{S}, \mathrm{G}$ & Perkins-Visser et al. (1996) \\
\hline A & Costa (1994) & A & Petrik et al. (1999) \\
\hline A & De Freitas (1986) & $\mathrm{S}$ & Pile et al. (1996) \\
\hline A & Dean \& Haldorson (2000) & A & Raposa \& Oviatt (2000) \\
\hline A & Dennis (1992) & $\mathrm{S}, \mathrm{G}$ & Ray \& Stoner (1995) \\
\hline A & Edgar \& Shaw (1995) & A & Robertson \& Duke (1987) \\
\hline A & Eggleston \& Etherington (1998) & G & Rooker et al. (1997) \\
\hline A & Gillanders (1997) & $\mathrm{S}$ & Rooker et al. (1998) \\
\hline A & Gray et al. (1996) & A & Rozas \& Minello (1998) \\
\hline A & Gray et al. (1998), Guidetti \& Bussoti (2000) & $\mathrm{S}$ & Ryer et al. (1997) \\
\hline A & Halliday (1995), Hanekom \& Baird (1984) & A & Sedberry \& Carter (1993) \\
\hline A & Haywood et al. (1995) & $\mathrm{A}, \mathrm{G}$ & Sogard (1992) \\
\hline A & Holt et al. (1983) & $\mathrm{S}$ & Stoner (1982) \\
\hline A & Howe \& Wallace (2000) & $\mathrm{S}$ & Stoner \& Sandt (1991) \\
\hline A & Hyndes et al. (1986) & A & Stoner \& Waite (1990) \\
\hline A & Jenkins \& Sutherland (1997) & G & Stoner et al. (1996) \\
\hline A & Jenkins \& Wheatly (1998) & A & Thomas et al. (1990) \\
\hline A & Jordan et al. (1996) & A & Tolan et al. (1997) \\
\hline A & Kenyon et al. (1997) & $\mathrm{A}, \mathrm{S}, \mathrm{G}$ & Tupper \& Boutilier (1995) \\
\hline $\mathrm{S}$ & Kenyon et al. (1999) & A & Weinstein \& Brooks (1983) \\
\hline $\mathrm{S}$ & Laprise \& Blaber (1992) & A & Williams et al. (1990) \\
\hline $\mathrm{A}, \mathrm{S}, \mathrm{G}$ & Levin et al. (1997) & $\mathrm{S}$ & Wilson et al. (1987) \\
\hline A & Loneragan et al. (1998) & $\mathrm{A}, \mathrm{S}$ & Wilson et al. (1990) \\
\hline $\mathrm{G}$ & Malloy et al. (1996) & A & Worthington et al. (1991), Young (1978) \\
\hline A & Mattilla et al. (1996) & A & Young \& Carpenter (1977) \\
\hline
\end{tabular}

However, it is important to recognize that metaanalysis is designed to combine the results of separate studies to reach general conclusions, and of necessity it overlooks some specifics of individual studies in a search for large patterns (Gurevitch \& Hedges 2001). Therefore, it is up to the individual carrying out the meta-analysis to ensure that the question being asked is best answered by meta-analytic techniques.

In our assessment, the data sets for survival and growth rates were considerably smaller, more manageable, and more similar in methodology across studies and thus, were more appropriate for meta-analysis. Because virtually no information was available on the success of movement of organisms from juvenile to adult habitats, and what little exists has recently been summarized by Gillanders et al. (in press), we do not consider this issue here.

Non-independence of data. In all analyses that combine or compare results across studies, non-independence of data is a recurrent issue and at some level may be unavoidable (for a discussion of nonindependence in meta-analysis see Gurevitch et al.
1992). Non-independence may occur because a number of experiments were performed by the same investigator or laboratory group; it also may occur because experiments were done in the same geographic region or on the same species. We investigated potential commonalities among data that shared the latter characteristics, but assumed that any non-independence caused by investigator or laboratory group would not substantially bias interpretation of results. Thus, if a study presented results of several experiments in a single publication, these experiments were usually entered as separate lines of data in the meta-analysis or vote-count. In our analysis of juvenile density in seagrass meadows versus other habitats, multiple censuses taken over consecutive years or at different sites were considered independent, only if it was clear that the temporal or spatial scale of replication meant that different cohorts or populations were being measured in each comparison. When a study provided density comparisons for multiple species, each species with an appropriate life history was entered into the vote-count indepen- 
dently. Inappropriate species, according to the definition in Beck et al. (2001), such as permanent seagrass residents, were removed from the analyses.

Deciding what constituted independent comparisons was more difficult in the survival and growth rate data sets than in the density data set, because papers in the first 2 groups tended to report the results of experiments rather than those of sampling efforts. Complications occurred in determining whether a given 'treatment' implemented by the authors actually constituted an independent comparison. Another issue arose when similar or identical field experiments were implemented in multiple seasons in the same location. Clearly, the individual organisms being tested differed between seasons, but other factors directly influencing survival or growth rate (e.g. the assemblage of predators) may have been constant over the time scale examined. To determine whether these decisions regarding independence qualitatively affected the results of the meta-analysis, we analyzed the data sets in 2 ways: (1) with each potential independent comparison entered separately; and (2) with all data 'lumped' into a single comparison.

Analysis of growth and survival data. To be included in the meta-analyses, each study had to provide 3 things: (1) the group mean, (2) SD and (3) sample size for both an 'experimental' group and a 'control'. In our analysis, the seagrass habitat was considered the experimental treatment, and the other habitat type the control. If this basic information could not be found or inferred from the paper, the study could not be used. In many cases, group means and some measure of variance were presented in the form of a graph, and we had to estimate parameters from them. If the SE was reported, $\mathrm{SD}=\mathrm{SE} / \mathrm{n}$, where $\mathrm{n}$ is sample size.

All analyses were performed using MetaWin 2.0 (Rosenberg et al. 2000). From the information culled from each individual study, we calculated an effect size for each independent comparison, using biascorrected Hedges' $d$ as our metric (Hedges \& Olkin 1985). Hedges' $d$ is calculated as:

$$
d=\frac{\left(\bar{X}^{\mathrm{E}}-\bar{X}^{\mathrm{C}}\right)}{S} J
$$

where $\bar{X}^{\mathrm{C}}$ is the mean of the control group, $\bar{X}^{\mathrm{E}}$ is the mean of the experimental group, and $S$ is the pooled SD of the 2 groups. $J$ corrects for the bias in the difference between group means caused by small sample size, and is calculated as:

$$
J=1-\frac{3}{4\left(N^{\mathrm{C}}+N^{\mathrm{E}}-2\right)-1}
$$

In our analysis, a positive value of $d$ would indicate greater survival or growth of juveniles in seagrass habitats than in alternative habitats, while a negative $d$ would indicate lower survival or growth in seagrass.

We then calculated the cumulative effect size $\left(d_{+}\right)$ across all studies in our database. The cumulative effect size is a weighted average of individual effect sizes, such that each $d$ is weighted by the reciprocal of its sampling variance (Hedges \& Olkin 1985). This effect was considered statistically significant if biascorrected $95 \%$ confidence intervals, calculated from 5000 bootstrap iterations, did not include 0 .

In addition to the cumulative effect size, we were interested in whether the effect size was homogeneous across those studies. The total heterogeneity of a sample, $Q_{\mathrm{t}}$ is comparable to the total sums of squares in an analysis of variance (Rosenberg et al. 2000); it is tested against a chi-square distribution to determine whether the variance among effect sizes in the data set is greater than would be expected by sampling error alone. We used a mixed model in our meta-analysis because its assumptions (i.e. a true random component of variation in effect sizes across studies in addition to sampling error) were more realistic than fixed-effects models, given the data sets and biological questions we attempted to address (Rosenberg et al. 2000).

\section{RESULTS}

\section{Density of juvenile organisms}

Our literature search detected 56 papers with survey data on the abundance of juvenile fish and invertebrates in seagrass meadows and other habitats (see Table 1). There clearly is a geographical bias, as the vast majority of these studies $(80 \%)$ were conducted in either North America (the USA and Canada) or Australia, with those remaining occurring in 5 other countries. Of the total 193 comparisons, 89 (46\%) showed greater abundance in seagrass, $50(26 \%)$ showed greater abundance in other habitats, and $54(28 \%)$ showed no difference between seagrass and other habitats. Thus, for slightly more than half of the species studied, seagrass meadows did not support abundances that were significantly greater than those in surrounding habitats.

This surprising result is due in large part to at least 2 major factors. One is that when seagrass meadows were either found not to differ significantly or to contain lower abundances than adjacent habitats, the adjacent habitats were often structurally complex habitats, such as mangroves, salt marshes, boulders or macroalgae. These structurally complex habitats are also often thought to serve as nursery habitats themselves, and our results suggest that various types of 
structurally complex habitats may often not differ in the density of animals they support.

A second factor is that there appears to be geographical patterns in the degree to which seagrass meadows support greater densities of animals than alternative habitats (Fig. 1). There is stronger evidence of the importance of seagrass meadows in the northern hemisphere, where 58 of 77 comparisons ( $75 \%$ ) showed significantly greater abundances in seagrass, than in the southern hemisphere, where only 42 of 116 (36\%) did (Fig. 1). Whether this pattern will hold up as more locations are investigated or whether other patterns may emerge must await the publication of additional studies from a broader variety of locations.

It is also important to note that 45 comparisons came from a single paper reporting the results of visual fish censuses (Nagelkerken et al. 2000), and that this single data set produced a very large number of the comparisons that did not find abundances in seagrass meadows to be either significantly greater (30 of 50 cases) or significantly different (15 of 54 cases) than in alternative habitats. Because the other data on density were gathered by researchers using standard sampling methods, such as seining or trawling, we are uncertain whether the results reported by Nagelkerken et al. (2000) reflect real biological differences between their sampling locations and other places, or whether they simply reflect differences due to dissimilar sampling methods. Presently, there is no way to separate these 2 possibilities. Another issue regarding the data in Nagelkerken et al. (2000) is that in some of the habitats they studied (e.g. coral reefs) adults were also inextricably included in their data sets. Since the evaluation of nursery function should not include adults, this is problematic. We were unable to assess the importance of including some adults from the data presented in the paper, but we feel it is necessary to point out this inconsistency lest undue emphasis be placed on this single data set. Finally, we point out that many species are found in seagrass meadows when they are very small, and for limited amounts of time (e.g. blue crab megalopae, as reported by Orth \& von Montfrans 1987, Pile et al. 1996). This means that the most commonly used sampling methods will not detect such taxa.

\section{Survival of juvenile organisms}

We identified 17 papers that contained information on the survival of juveniles, 8 pertaining to fish and 9 pertaining to invertebrates (Table 1), and the vast majority of these papers was from North America (Table 2). From these 17 papers, 71 comparisons were identified when we allowed the following to be considered: (1) field experiments that were repeated over the course of a season (e.g. Ryer 1987, Wilson et al. 1990); (2) a series of lab trials from Pile et al. (1996) testing survival of different blue crab instars; and (3) replicate experiments in Olmi \& Lipcius (1991). When replicated experiments were not considered to be independent, the data set was reduced to 57 comparisons. Hedges' $d$-values calculated from these comparisons varied considerably, ranging from -9.4551 to 7.6859 (Fig. 2).

When all studies were considered together in the unlumped data set, seagrasses had a significantly positive effect on juvenile survival when compared to other habitats $\left(d_{+}=0.9098, \mathrm{CI}: 0.1278\right.$ to 1.5803$)$. By convention, $d>0.8$ is considered large, and implies that the mean and control groups differ by greater than 0.8 SD (Cohen 1969). When all temporal replicates and data from the Pile et al. (1996) laboratory studies were pooled; however, the cumulative effect size dropped to medium-large $\left(d_{+}=0.6579\right)$ and the confidence intervals bracketed 0 . In both cases, the $Q_{\mathrm{t}}$ was large and significant, implying the existence of underlying structure in the data set.

We categorized the 'control' or other habitat from each individual study into 3 broad classes: (1) no structure (e.g. sand, soft sediment, etc.); (2) non-vegetated structure (e.g. cobble, oyster reef, etc.); and (3) vegetated structure (e.g. macroalgae, salt marsh). In both the lumped and unlumped versions of the survival data set, we found significant differences in the mean effect

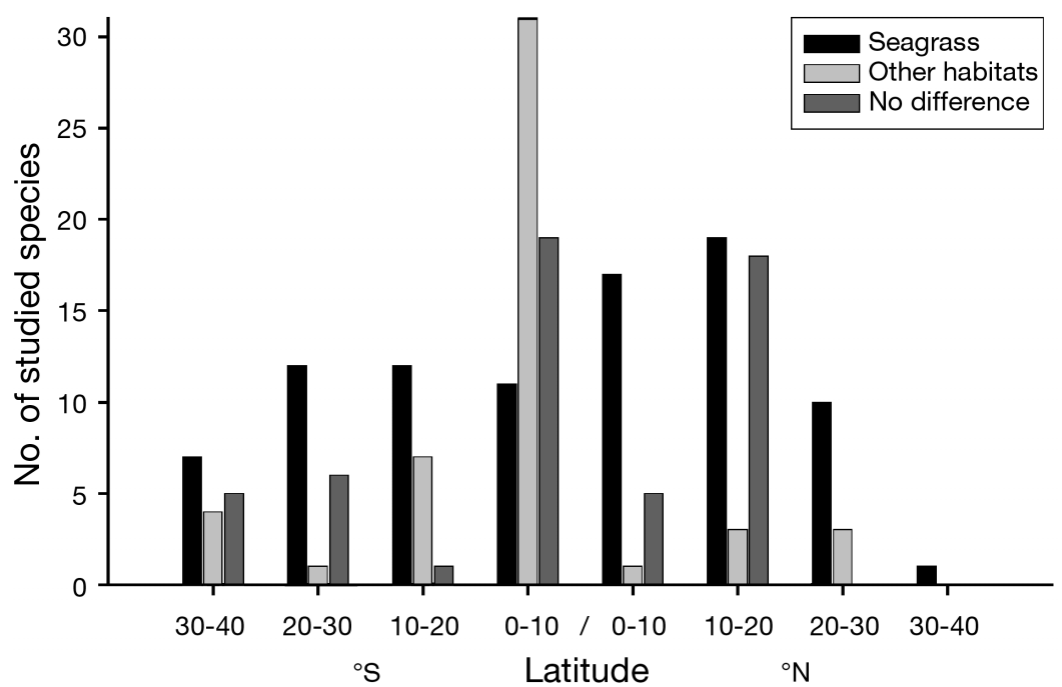

Fig. 1. Number of fish and invertebrate species showing significantly greater abundance or no significant difference in abundance between seagrass meadows and other habitats, as a function of latitude 
Table 2. Number of independent comparisons in the data sets on growth and survivorship of juvenile organisms in seagrass meadows and other habitats. 'Lumped' and 'Unlumped' refer to whether debatably independent treatments in a given study (e.g. temporal replicates; see 'Materials and methods') were pooled

\begin{tabular}{|c|c|c|c|c|c|}
\hline \multicolumn{3}{|c|}{ Survival rate } & \multicolumn{3}{|c|}{ Growth rate } \\
\hline Methodology & & & Methodology & & \\
\hline Field studies & 33 & 41 & Field studies & 54 & 87 \\
\hline Laboratory studies & 24 & 30 & Laboratory studies & 4 & 4 \\
\hline Regions represented & & & Regions represented & & \\
\hline Chesapeake Bay, USA & 11 & 19 & VA, USA & 9 & 9 \\
\hline Bahamas & 4 & 4 & Bahamas & 9 & 29 \\
\hline Nova Scotia & 9 & 9 & Nova Scotia & 4 & 4 \\
\hline TX, USA & 14 & 14 & Galveston Bay, TX, USA & 1 & 2 \\
\hline Australia & 7 & 7 & Sendari Bay, Japan & 3 & 3 \\
\hline Belize & 2 & 2 & FL, USA & 3 & 3 \\
\hline NJ, USA & 6 & 12 & NJ, USA & 28 & 40 \\
\hline Mobile Bay, AL, USA & 4 & 4 & $\mathrm{NC}, \mathrm{USA}$ & 1 & 1 \\
\hline Species represented & & & Species represented & & \\
\hline Callinectes sapidus & 25 & 39 & Callinectes sapidus & 4 & 4 \\
\hline Gadus morhua & 9 & 9 & Gadus morhua & 9 & 9 \\
\hline Panulirus argus & 2 & 2 & Kareius bicoloratus & 1 & 2 \\
\hline Penaeus aztecus & 2 & 2 & Lagodon rhomboides & 2 & 2 \\
\hline Penaeus esculentus & 7 & 7 & Pseudopleuronectes americanus & 16 & 22 \\
\hline Sciaenops ocellatus & 8 & 8 & Sciaenops ocellatus & 2 & 2 \\
\hline Strombus gigas & 4 & 4 & Tautoga onitis & 12 & 18 \\
\hline Total & 57 & 71 & Total & 58 & 91 \\
\hline
\end{tabular}

sizes calculated for these groups $(\mathrm{p}<0.0001$ in both cases; Table 3). Survival of juvenile organisms was significantly higher in seagrasses than in unstructured habitats $\left(d_{+}=2.0755\right.$ unlumped or 2.0459 lumped) and significantly lower in seagrasses than in habitats that had structure but were not vegetated $\left(d_{+}=-3.0959\right.$ lumped or -3.1008 unlumped). When seagrass meadows and vegetated habitats, such as macroalgal beds, were compared, there was no detectable difference in juvenile survival $\left(d_{+}=0.0618\right.$ lumped or

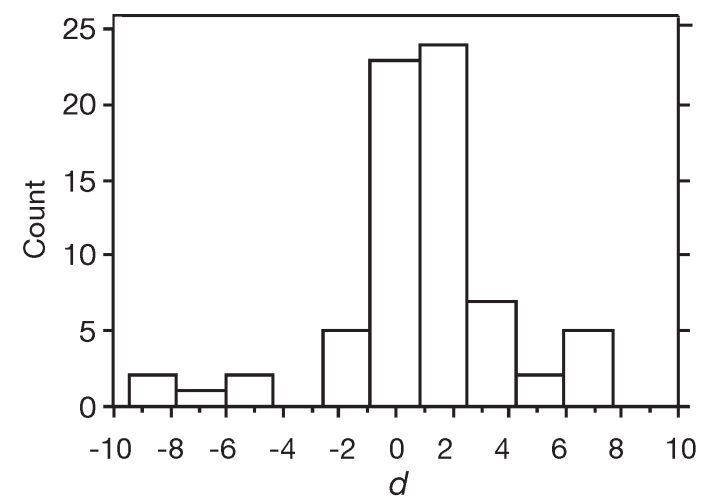

Fig. 2. Juvenile survival in different habitats. Frequency histogram of Hedges' $d$-values calculated from the data set on juvenile survival in different habitats. A positive value of $d$ indicates greater survival of juveniles in seagrass meadows than other habitats; a negative $d$-value indicates lower survival in seagrass meadows than alternative habitats
-0.0136 unlumped; Fig. 3). $Q_{t}$ in the mixed-model remained very large and significant in both versions of the data set $\left(Q_{\mathrm{t}}=126.70\right)$. We decided not to pursue a finer-scale analysis of other habitat types due to concern about sample size (in our data set, specific habitats were represented by very few comparisons (e.g. intertidal marsh creek $n=2$ ), as well as the fact that these comparisons were likely to come from the same paper.

When only comparisons between seagrass meadows and unstructured habitats were considered, there was

Table 3. Juvenile survival in seagrass meadows compared to 3 categories of other habitat types. Values reported are mean effect size for each category $\left(d_{+}\right)$, degrees of freedom $(\mathrm{df}=$ number of comparisons - 1) and bias-corrected $95 \% \mathrm{CI}_{\text {, }}$ calculated when temporally replicated experiments, etc., were entered separately into the data set (see 'Materials and methods' for criteria); when these data were pooled, there was no qualitative difference in the results of the meta-analysis. ${ }^{*}$ Mean effect size is significantly different from zero $(\mathrm{p}<$ 0.05). $Q_{\mathrm{t}}$ is a heterogeneity statistic; a significant $Q_{\mathrm{t}}$ indicates significant differences in mean effect size between habitat categories. $Q_{\mathrm{t}}=46.5046, \mathrm{df}=2, \mathrm{p}<0.00001$

\begin{tabular}{|lrcc|}
\hline Alternate habitat type & $d_{+}$ & df & CI \\
\hline No structure & 2.0755 & 46 & 1.5038 to $2.7491^{*}$ \\
Unvegetated structure & -3.0959 & 10 & -5.6940 to $-0.5925^{*}$ \\
Vegetated structure & 0.0618 & 12 & -0.3199 to 0.5651 \\
\hline
\end{tabular}




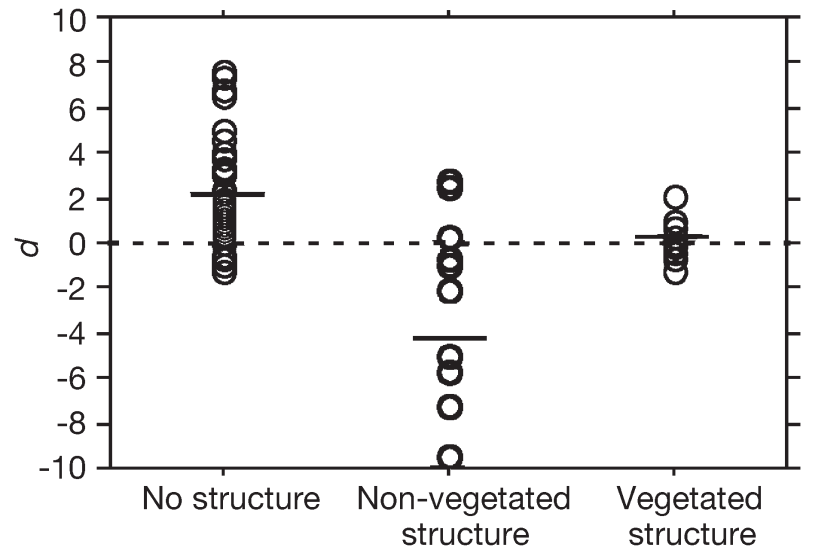

Fig. 3. Juvenile survival in seagrass meadows versus 3 broad categories of other habitat types as a scatter plot of Hedges' $d$-values. (1) Unstructured habitats, (2) habitats that are structured but non-vegetated, (3) vegetated habitats. Dashed line at $d=0$ indicates no difference between survival in seagrass and alternate habitat; solid horizontal lines represent mean $d$ for each group

no effect of methodology (laboratory vs field studies) on the estimate of overall effect size (Table 4). Both types of experiments showed a significant positive effect of seagrass on juvenile survival, although confidence intervals around the mean effect size in field experiments were somewhat larger. In contrast, methodology did have a significant effect on whether a given study detected a difference in juvenile survival between seagrass and structured-unvegetated habitats (Table 4). Field-based experiments found a large, significantly negative effect of seagrass on juvenile survival in comparison to structured-unvegetated habitats; laboratory-based experiments could detect no difference between habitats. In comparisons between seagrass meadows and other vegetated habitats, we found no effect of methodology on effect size in the unlumped data set, but in the more conservative, lumped data set, field studies detected a significant negative effect while laboratory studies found no difference between habitats (Table 4).

The effect of seagrass meadows on juvenile survival clearly varied across species (Fig. 4) with no discernable patterns by taxonomy (fish vs decapod crustaceans) or geography (tropical vs temperate).

\section{Growth rate of juvenile organisms}

We identified 11 papers that contained information on the growth rate of juveniles that satisfied our initial selection criteria (Table 1). Eight different species (blue crab Callinectes sapidus, queen conch Strombus gigas and 6 fish species), $75 \%$ of which were
Table 4. Effect of methodology on comparisons of juvenile survival in seagrass meadows and other habitat types. Each alternate habitat type was tested separately. Values reported are mean effect size for each category $\left(d_{+}\right)$, degrees of freedom (df) and bias-corrected $95 \%$ CI. ${ }^{*}$ Mean effect size is significantly different from 0 . A significant $Q_{\mathrm{t}}$-value indicates a significant difference between mean effect sizes measured by lab and field studies. Only in the seagrass versus vegetated habitat comparison did decisions regarding pooling of data cause a qualitative difference in the meta-analysis results; results of both sets of analysis for that comparison are presented below

\begin{tabular}{|c|c|c|c|}
\hline Methodology & $d_{+}$ & $\mathrm{df}$ & $\mathrm{CI}$ \\
\hline \multicolumn{4}{|c|}{ Seagrass vs unstructured habitats } \\
\hline Lab studies & 1.9595 & 21 & 1.2533 to $2.7621^{*}$ \\
\hline Field studies & 2.1792 & 24 & 1.3418 to $3.2753^{*}$ \\
\hline \multicolumn{4}{|c|}{$Q_{\mathrm{t}}=0.1341, \mathrm{df}=1, \mathrm{p}=0.72$} \\
\hline \multicolumn{4}{|c|}{ Seagrass vs structured, unvegetated habitats } \\
\hline Lab studies & 1.1585 & 3 & -0.3121 to 2.6782 \\
\hline Field studies & -5.6888 & 6 & -7.9490 to $-3.3805^{*}$ \\
\hline \multicolumn{4}{|c|}{$Q_{\mathrm{t}}=19.2428, \mathrm{df}=1, \mathrm{p}<0.00001$} \\
\hline \multicolumn{4}{|c|}{ Unlumped: Seagrass vs vegetated habitats } \\
\hline Lab studies & 0.4294 & 3 & 0.0492 to $0.9130^{*}$ \\
\hline Field studies & -0.0802 & 8 & -0.5576 to 0.6805 \\
\hline \multicolumn{4}{|c|}{$Q_{\mathrm{t}}=1.2867, \mathrm{df}=1, \mathrm{p}=0.26$} \\
\hline \multicolumn{4}{|c|}{ Lumped: Seagrass vs vegetated habitats } \\
\hline Lab studies & 0.3818 & 3 & -0.0685 to 0.7129 \\
\hline Field studies & -0.4844 & 5 & -0.7303 to $-0.0320^{*}$ \\
\hline \multicolumn{4}{|c|}{$Q_{\mathrm{t}}=8.0928, \mathrm{df}=1, \mathrm{p}<0.01$} \\
\hline
\end{tabular}

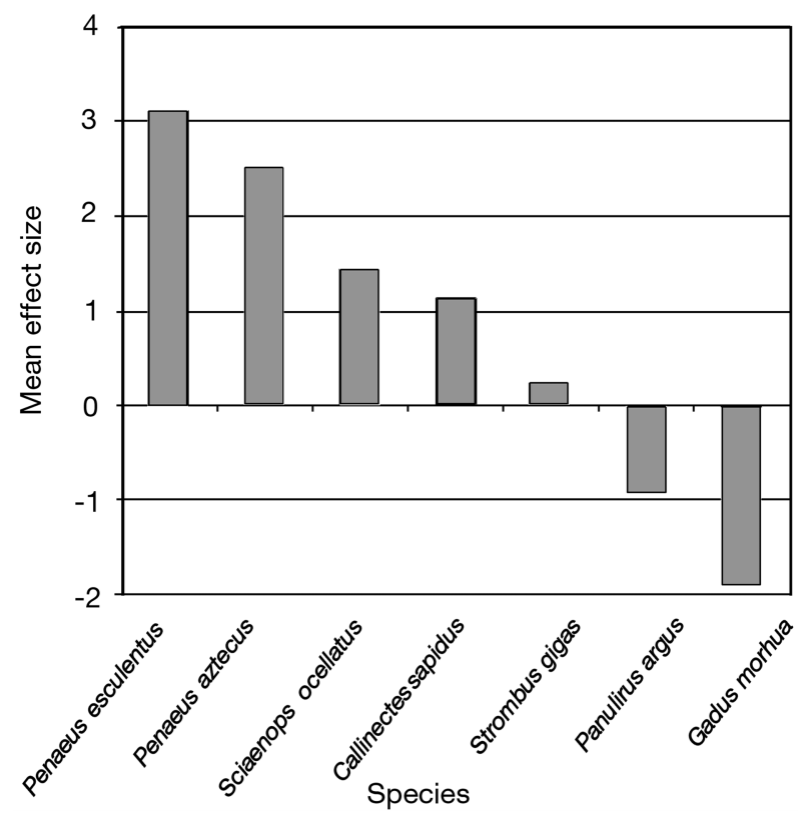

Fig. 4. Unweighted mean effect size (Hedges' $d$ ) for each species represented in the data set on juvenile survival, averaged over all other habitats tested. Positive effect sizes indicate greater survival of juveniles of that species in seagrass meadows than in the other habitats tested; negative effect sizes indicate lower survival of juveniles in seagrass than in other habitats 


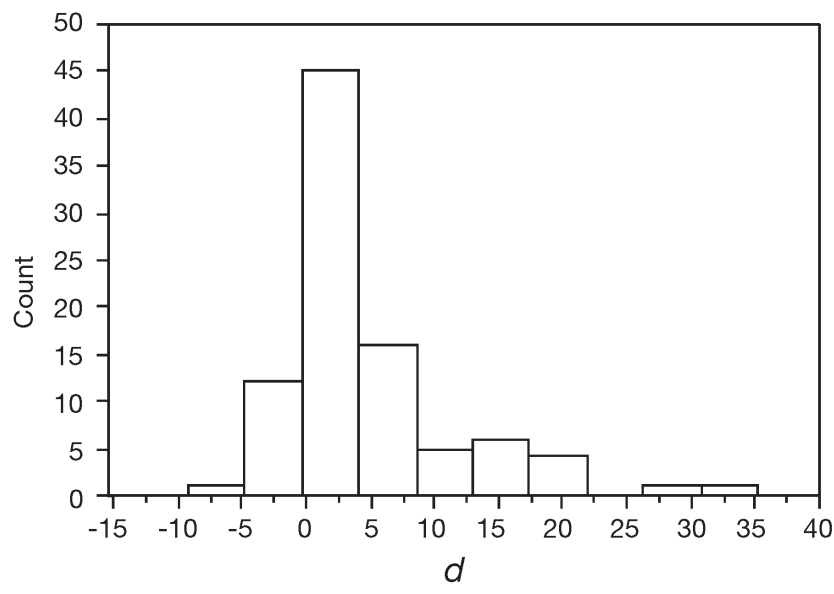

Fig. 5. Juvenile growth rates in seagrass habitats. Frequency histogram of Hedges' $d$-values calculated from the data set on juvenile growth rates in seagrass habitats. A positive value of $d$ indicates greater growth of juveniles in seagrass meadows than other habitats; a negative $d$-values indicates lower growth rate

North American, contributed to the data set (Table 2). From the 11 papers, 91 comparisons were identified when we allowed: (1) experiments that were repeated at a given site at different times in a season (e.g. Stoner \& Sandt 1991, Phelan et al. 2000); and (2) experiments that assessed growth of different size classes of queen conch to be entered independently (Ray \& Stoner 1995). When these were not considered independent, the data set contained 58 comparisons. All but 4 comparisons came from field experiments.

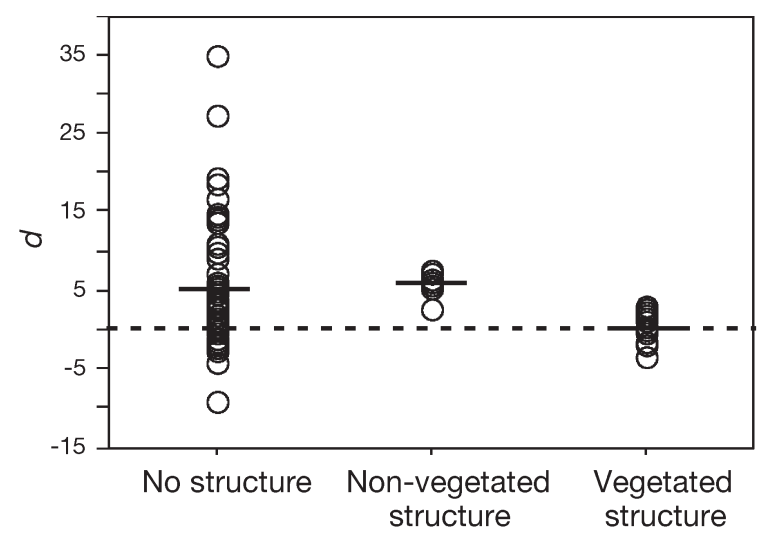

Fig. 6. Comparisons of juvenile growth rates in seagrass meadows and in 3 categories of other habitat types as a scatter plot of Hedges' $d$-values. (1) Unstructured habitats, (2) habitats that are structured but non-vegetated, (3) vegetated habitats. Hatched horizontal line at $d=0$ indicates no difference between growth rates in seagrass and the alternative habitat; solid vertical lines represent mean $d$ for each group
The exceptions were Perkins-Visser et al.'s (1996) study of blue crab growth rate in experimental microcosms, and Stoner et al.'s (1996) study of queen conch metamorphosis and growth rate in response to different cues in the lab. The range of Hedges' $d$-values calculated from these individual lines of data was also extremely large, ranging from -9.1944 to 35.1975 (Fig. 5)

When all studies were considered together, juvenile organisms had much greater growth rates in seagrass meadows than in other habitats, regardless of decisions about the independence of temporal replicates (unlumped $d_{+}=4.2871$, CI: 3.0206 to $5.8611_{\text {; lumped } d_{+}}$ $=4.1249$, CI: 2.5482 to 6.0608 ). There were no qualitative differences between results of any of the subsequent analyses on the lumped and unlumped growth rate data sets, so for brevity, we present only the analyses of the larger data set.

The magnitude of the difference between growth rates in seagrass meadows and other habitats depended on the other habitat type being tested ( $p<$ 0.05; Fig. 6). In comparisons with unstructured and structured-unvegetated habitats (categories defined as above), the effect size was extremely large $\left(d_{+}=6.0676\right.$ and 5.2796, respectively) and statistically significant (Table 5). However, as was the case with juvenile survival, there was no significant difference in juvenile growth rate in seagrass meadows compared to vegetated habitats such as macroalgal beds and salt marshes.

Species specific comparisons of mean effects size showed that 3 species of fishes and 2 invertebrates grew more rapidly in seagrass than in other habitats, while 2 fish species grew more rapidly in alternative habitats (Fig. 7). The small sample size precluded the identification of either taxonomic or geographical patterns.

Table 5. Juvenile growth rates in seagrass meadows versus 3 categories of other habitat types. Values reported are mean effect size for each category $\left(d_{+}\right)$, degrees of freedom (df) and bias-corrected $95 \%$ CI calculated when temporally replicated experiments, etc., were entered separately into the data set (see 'Materials and methods' for criteria); when these data were pooled, there was no qualitative difference in the results of the meta-analysis. ${ }^{*}$ Mean effect size is significantly different from zero $(\mathrm{p}<0.05) . Q_{\mathrm{t}}$ is a heterogeneity statistic; a significant $Q_{\mathrm{t}}$ indicates significant differences in mean effect size between habitat categories. $Q_{\mathrm{t}}=6.0588, \mathrm{df}=2, \mathrm{p}<0.05$

\begin{tabular}{|lccc|}
\hline Alternate habitat type & $d_{+}$ & df & CI \\
\hline Unvegetated structure & 6.0676 & 7 & 4.8774 to $6.9453^{*}$ \\
No structure & 5.2796 & 61 & 3.4915 to $7.5875^{*}$ \\
Vegetated structure & 0.6627 & 20 & -0.0927 to 1.2563 \\
\hline
\end{tabular}




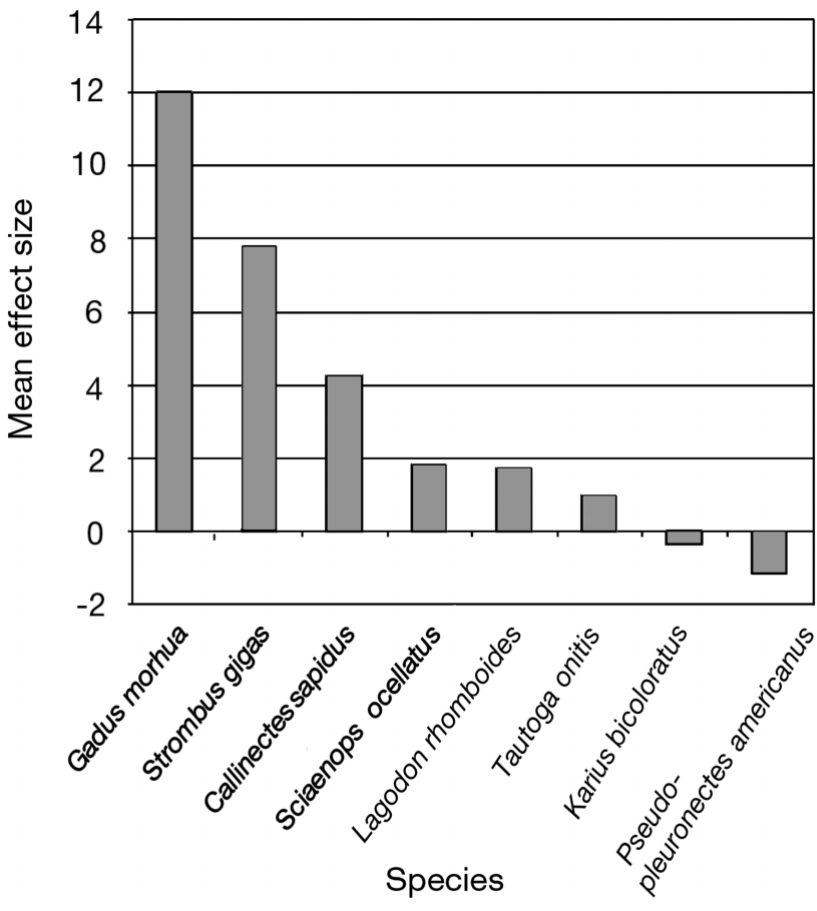

Fig. 7. Unweighted mean effect size (Hedges' $d$ ) for each species represented in the data stet on juvenile growth rates, averaged over all other habitats tested. Positive effect sizes indicate that juveniles of that species exhibited greater growth in seagrass meadows compared to the other habitats tested; negative effect sizes indicate less growth in seagrass than in other habitats

\section{DISCUSSION}

\section{Density of juveniles}

The number of papers reporting the density of juvenile organisms in seagrass meadows and surrounding habitats that we identified in our literature search may seem low, considering the many surveys done in seagrass habitats in the last several decades. However, many studies were not included in our vote-count because only seagrass meadows were sampled or because only aggregate measures of animal abundance (e.g. total biomass or number of individuals per square meter) were reported. Although the total biomass of consumers in different habitats cannot be used to demonstrate a nursery function as we have defined it, biomass does imply something about how a habitat may function as a nursery at the ecosystem level. If there is greater production of consumers (residents included) in seagrass habitats than in other nearshore habitats (e.g. Edgar 1990, Fredette et al. 1990, Valentine \& Heck 1993), this may translate to greater 'spillover' or export of organisms and nutrients into adjacent habitats (see Childers et al. unpubl., for a dis- cussion on how the nursery concept can be better understood by integrating both population and ecosystem level approaches).

Another issue that we did not consider is the possible relationship between species diversity and the definition of a nursery. The high species diversity of animals in seagrass meadows relative to surrounding habitats has long been noted by researchers (see reviews by Orth et al. 1984, Bell \& Pollard 1989, Orth 1992), although the magnitude of this difference is dependent on both the species composition and biomass of the seagrass species. While such elevated animal species numbers are not accounted for in our nursery definition, the maintenance of high species numbers by seagrass meadows is another feature relevant to the perception of these habitats as extraordinarily rich.

\section{Survival and growth}

As expected, significantly greater survival in seagrass meadows than on unvegetated substrate was indicated by our meta-analysis. However, there was little difference between the amount of protection provided by seagrasses and other structurally complex habitats such as salt marshes or oyster reefs. Thus, the enhanced survival of organisms in seagrass compared to that observed on unvegetated substrates seems to be due primarily to the simple effect of structure and not some intrinsic property of the seagrasses themselves.

Further, although there were relatively few studies that met our strict criteria for assessing the role of seagrasses in providing protection from predation, primarily because our comparisons were restricted to taxa with spatially separated juvenile and adult habitats, there are many other studies that have investigated the protection provided by seagrasses for a variety of resident invertebrate and some fish species (reviewed by Orth et al. 1984, Heck \& Crowder 1991, Heck et al. 1997). Over a period of more than $20 \mathrm{yr}$, virtually all these studies have found significantly greater survival in the presence than in the absence of seagrasses, whether in the laboratory (Nelson 1979, Coen et al. 1981, Main 1987, Mattila 1995) or in the field (Leber 1985, Heck \& Wilson 1987, Heck \& Valentine 1995). Although the taxa in these studies do not use seagrass meadows as nursery habitats according to our criteria, it is clear that they can and do contribute substantially to the export of energy from seagrass meadows through trophic transfer, and thereby provide energy subsidies for both adjacent and distant ecosystems (see Childers et al. unpubl., Halpern \& Beck unpubl.). Most investigators cited above concluded, incorrectly according to our criteria, that their results provided evidence of the nursery role of seagrass meadows. 
Nevertheless, these studies are clearly relevant to, if not entirely consistent with, the nursery definition of Beck et al. (2001).

Growth was also significantly greater in seagrass than on unvegetated substrates, although there was little difference between growth in seagrass and other structured habitats. This also indicates that it is structure per se rather than some property of the seagrasses that leads to enhanced growth. Indeed, it may well be that greater growth in structured habitats occurs because structure provides more protection from predators and thereby allows more time for feeding, and thus significantly greater growth rates, than is possible in unstructured habitats. It is also true that structure provides more substrate for food resources to grow upon which can be an important factor influencing growth rates.

\section{Case histories for the nursery hypothesis}

Dramatic, large-scale losses of seagrass could potentially offer insights into the validity of the nursery role hypothesis if harvests of commercially exploitable species that are purported to be dependent on seagrass beds for nurseries were examined. The expectation would be that, all other things being equal, harvests should decline. At least 3 such cases exist, one from the 1930s and 2 from more recent times.

One of the most dramatic changes in seagrass abundance was the precipitous decline of eelgrass Zostera marina in the 1930s. Eelgrass populations along both the European and North American coasts virtually disappeared over several years, which was attributed to, but never fully verified, a slime mold parasite in the genus Labyrinthula (Rasmussen 1977). Prior to the decline, eelgrass was considered the most important nursery for most of the commercial fisheries in the European North Atlantic (Peterson \& Boysen-Jensen 1911). These fisheries did not, however, collapse following the eelgrass decline and the emphasis on eelgrass as an important nursery habitat waned in the ensuing years. However, the situation was complicated by the fact that the substrate in former eelgrass habitat apparently underwent changes as sediment was eroded after seagrass disappearance, thereby exposing rocky substrate. The rocks were subsequently colonized by macroalgae that offered an alternative 'nursery' habitat (Rasmussen 1977). Therefore, it was argued that the loss of the eelgrass nursery was simply replaced by a macroalgae nursery and this explained why no dramatic reduction in fisheries yields occurred.

One of the more recent changes involved seagrass meadows dominated by turtlegrass Thalassia testudi- num in Florida Bay. These seagrass beds are believed, based on a great deal of long-term data, to serve as the primary nursery habitat for pink shrimp Farfantepenaeus duorarum harvested from the Tortugas, FL shrimping grounds (Browder et al. 1999, Fry et al. 1999). If this was true, the dramatic loss of turtlegrass from Florida Bay in the late 1980s (Robblee et al. 1991, Hall et al. 1999) should have led to reduced yields of pink shrimp in the years following turtlegrass loss.

Pink shrimp yields (CPUE) did decrease in the years following turtlegrass decline, as predicted (Sheridan 1997), and they stayed low for approximately $5 \mathrm{yr}$ before increasing in the mid-1990s (Browder et al. 1999, Ehrhardt \& Legault 1999). This is in general agreement with expectations, although the increase in landings in the mid-1990s was not coincident with seagrass recovery (Browder et al. 1999). However, other factors are known to be positively correlated with pink shrimp population fluctuations. In particular, there is a positive relationship between freshwater input to Florida Bay and the harvest of pink shrimp (Browder 1985, Sheridan 1997). Coincident with decreasing yields in the late 1980s, there had been a drought in South Florida (Swart et al. 1999). To those most knowledgeable, it appears likely that low freshwater inputs played a major role in the decreased shrimp harvests in the early 1990s (Browder et al. 1999). Thus, what at first appeared to be a clear verification of the nursery role of turtlegrass for pink shrimp appears to be substantially more complicated.

A second seemingly clear recent test of the nursery role of seagrass meadows concerns eelgrass Zostera marina abundance and the harvest of blue crabs Callinectes sapidus in the Chesapeake Bay, during the 1970s. During this time the Chesapeake Bay lost large amounts of submerged aquatic vegetation (SAV), which included both oligohaline species such as Potamogeton pectinatus and $P$. perfoliatus, as well as polyhaline species such as eelgrass (Orth \& Moore 1983). The prediction was that species relying heavily on SAV as nursery habitat, such as the blue crab, would show large decreases in abundance after the decline of SAV. However, there is little evidence that blue crab landings declined substantially after SAV loss (Lipcius \& Van Engel 1990) This may have been because most SAV losses occurred in the upper part of the Chesapeake Bay, while the major habitat for settlement of postlarvae reentering the Bay from offshore oceanic waters, as well as early instar juveniles, are the eelgrass meadows of the lower polyhaline Chesapeake Bay (Orth et al. 1996), which declined much less than the oligohaline meadows of the upper Bay (Orth \& Moore 1983). As described above for pink shrimp in Florida Bay, there is neither a clear test nor a verification of the nursery hypothesis for the blue crab in the 
Chesapeake Bay, other than densities of juveniles being significantly higher and survival greater in eelgrass meadows than in unvegetated areas.

\section{Summary and recommendations for future research}

Although the concept of seagrass meadows as nursery habitats is a common theme in the literature, surprisingly few studies have actually established criteria for evaluating the nursery role hypothesis and even fewer have tested it. Most studies concerning the nursery role of seagrasses only consider the density of animals and, based on the greater densities often found in seagrass versus unstructured habitats, have inferred the importance of seagrass meadows as nurseries. Among those few studies of growth and survival that do exist, most indicate that structure per se, and not anything inherent to seagrasses themselves, is the main cause of elevated growth and survival in seagrasses compared to unvegetated substrates. In aggregate, we believe that the evidence indicates that the factor most often limiting animal populations in shallow coastal water is the shelter from predators that structured habitats provide. While larval supply and food resources are well known to limit some populations, our data provide no evidence of the importance of differential larval supply rates or of food availability among different types of structured habitats. But is important to note that almost no studies have yet measured the amount of successful movement from the purported seagrass nursery habitat to that of adults.

Any general conclusions to be drawn from the literature that we have reviewed must be tempered by the fact that a very large percentage of existing work has been done in only 2 continents: North America and Australia. This geographically limited data set suggests that the nursery role of seagrasses in the Northern Hemisphere (North America) may be larger than in the Southern Hemisphere (Australia). This conclusion was reached previously by Butler \& Jernakoff (2000) for commercially important species in Australia, but seems paradoxical given the enormous stands of seagrasses that occur along the entire lengths of Australia's temperate and subtropical coastlines.

It is clear that many more experimental studies on growth and survival in seagrass and other habitats are needed in all parts of the world but especially in areas other than North America and Australia. However, there is still much to be learned from these 2 continents as well, as the small number of studies in our metaanalyses indicates. Of critical importance is to test the nursery hypothesis not only by reporting animal densities, but also by estimating growth and survival rates, and the amount of successful movement of juveniles from putative nurseries to adult habitats. The latter issue is difficult to address but should be advanced by future studies that use otolith microchemistry to identify the juvenile habitats of individuals in the adult habitat (e.g. Gillanders \& Kingsford 1996), as well as new tagging technologies. We must also compare multiple habitats with respect to their nursery role, but in so doing we should be aware that some taxa may only utilize seagrass meadows for short periods of time and at very small sizes (e.g. early crab instars), which necessitates carefully focused and timed studies. Most species can be found in more than 1 habitat; however, there are surprisingly few studies that make comparisons among more than 2 potential nursery habitats.

Finally, seagrasses (and wetlands) have been the focus of most work on nurseries and, in most cases, this has been justified. Substantial evidence does support the contention that some seagrasses meadows serve as nursery habitats (e.g. Heck et al. 1997, Butler \& Jernakoff 2000) even though definitive tests of the nursery hypothesis are rare. Nevertheless, not all seagrass meadows are likely to be equal in their nursery function. If it were known, for example, that for many fish and invertebrate species the best seagrass nurseries were near sources of larval influx (e.g. coastal inlets) or in close proximity to adult habitats, then efforts to preserve or restore nurseries could be concentrated on such sites. It is also important to note that seagrasses also provide many ecosystem services and serve many important functions in addition to their potential as nurseries (e.g. Costanza et al. 1997). They stabilize shorelines, reduce wave impacts, remove suspended solids, recycle nutrients and oxygenate surrounding waters (Short \& WyllieEcheverria 1996, Costanza et al. 1997). Seagrasses are, of course, highly productive and much seagrass carbon enters coastal food webs through many different pathways.

As Beck et al. (2001) have emphasized, better testing of the nursery hypothesis for seagrass meadows and other habitats will allow the identification of habitats most worthy of protection and conservation, and more rigorous testing may show that previously overlooked habitats also serve as important nurseries and should be better conserved and managed. However, it is not necessary or prudent to wait for irrefutable evidence of any given habitat's nursery role before action is taken to conserve, manage or restore such habitats. Rather, we too believe that it is appropriate to err on the side of caution and to act on current knowledge of the suspected nursery value of different habitats (Beck et al. 2001).

Acknowledgements. S. Harter, S. Marion and D. Combs assisted in the literature search, and T. Spitzer and C. Wood helped greatly in manuscript preparation and review. We also appreciate the comments of our colleagues in the Wetlands 
Working Group, whose work was supported by a grant to M. W. Beck and K.L.H. Jr. from the National Center for Ecological Analysis and Synthesis, a Center funded by the US National Science Foundation (Grant \#DEB-0072909) at the University of California, Santa Barbara.

\section{LITERATURE CITED}

Arrivillaga A, Baltz D (1999) Comparison of fishes and macroinvertebrates on seagrass and bare-sand sites on Guatemala's Atlantic coast. Bull Mar Sci 65(2):301-319

Bayer RD (1981) Shallow-water intertidal ichthyofauna of the Yaquina Estuary, Oregon. Northwest Sci 55(3):182-193

Beck MW, Heck KL, Able KW, Childers DL and 9 others (2001) The identification, conservation, and management of estuarine and marine nurseries for fish and invertebrates. BioScience 51(8):633-641

Bell JD, Pollard DA (1989) Ecology of fish assemblages and fisheries associated with seagrasses. In: Larkum AWD, McComb AJ, Shepard SA (eds) Biology of seagrasses: a treatise on the biology of seagrasses with special reference to the Australian region. Elsevier, Amsterdam, p 565-609

Bell J, Westoby M (1987) Fish larvae settling in seagrasses: Do they discriminate between beds of different leaf density? J Exp Mar Biol Ecol 111:133-144

Briggs PT, O'Connor JS (1971) Comparison of shore-zone fishes over naturally vegetated and sand-filled bottoms in Great South Bay. NY Fish Game J 18(1):17-41

Browder JA (1985) Relationship between pink shrimp production on the Tortugas grounds and water flow patterns in the Florida everglades. Bull Mar Sci 37:839-856

Browder JA, Restrepo VR, Rice JK, Robblee MB, Zein-Eldin ZZ (1999) Environmental influences on potential recruitment of pink shrimp, Farfantepanaeus duorarum, from Florida Bay nursery grounds. Estuaries 22:484-499

Butler AJ, Jernakoff P (2000) Seagrass in Australia: strategic review and development of an $\mathrm{R} \& \mathrm{D}$ plan. CSIRO Publishing, Collingwood

Coen LD, Heck KL, Able LG (1981) Experiments on competition and predation among shrimps of seagrass meadows. Ecology 62:1484-1493

Cohen J (1969) Statistical power analysis for the behavioral sciences. Academic Press, New York

Connell JH (1983) On the prevalence and relative importance of interspecific competition: evidence from field experiments. Am Nat 122:661-696

Connolly RM (1994a) A comparison of fish assemblages from seagrass and unvegetated areas of a southern Australian estuary. Aust J Mar Freshw Res 45:1033-1044

Connolly RM (1994b) Removal of seagrass canopy: effects on small fish and their prey. J Exp Mar Biol Ecol 184:99-110

Costa MJ (1994) Do eelgrass beds and salt marsh borders act as preferential nurseries and spawning grounds for fish? An example of the Mira estuary in Portugal. Ecol Eng 3: 187-195

Costanza R, d'Arge R, De Groot R, Fraber S and 9 others (1997) The value of the world's ecosystem services and natural capital. Nature 387:253-260

Dean T, Haldorson L (2000) The distribution of nearshore fishes in kelp and eelgrass communities in Prince William Sound, Alaska: associations with vegetation and physical habitat characteristics. Environ Biol Fish 57:271-287

De Freitas AJ (1986) Selection of nursery areas by 6 Southeast African Penaeidae. Estuar Coast Shelf Sci 23:901-908

den Hartog C (1970) The sea-grasses of the world. NorthHolland, Amsterdam
Dennis GD (1992) Island mangrove habitats as spawning and nursery areas for commercially important fishes in the Caribbean. Proc Gulf Caribb Fish Inst 42:205-225

Edgar GJ (1990) The influence of plant structure on the species richness, biomass and secondary production of macrofaunal assemblages associated with Western Australia seagrass beds. J Exp Mar Biol Ecol 137:215-240

Edgar GJ, Shaw C (1995) The production and trophic ecology of shallow-water fish assemblages in southern Australia: I. Species richness, size-structure and production of fishes in Western Port, Victoria. J Exp Mar Biol Ecol 194:53-81

Eggleston DB, Etherington LL (1998) Organism response to habitat patchiness: species and habitat-dependent recruitment of decapod crustaceans. J Exp Mar Biol Ecol 223: $111-132$

Ehrhardt NM, Legault CM (1999) Pink shrimp, Farfantepenaeus duorarum, recruitment variability as an indicator of Florida Bay dynamics. Estuaries 22:471-483

Fredette TJ, Diaz R, van Montfrans JJ, Orth RJ (1990) Secondary production within a seagrass bed (Zostera marinaRuppia maritima) in lower Chesapeake Bay. Estuaries 13: 431-440

Fry B, Mumford PL, Robblee MB (1999) Stable isotope studies of pink shrimp (Farfantepenaeus duorarum Burkenroad) migrations on the southwestern Florida shelf. Bull Mar Sci 65:419-430

Gillanders BM (1997) Patterns of abundance and size structure in the blue groper, Achoerodus viridis (Pisces, Labridae): evidence of links between estuaries and coastal reefs. Environ Biol Fish 49(2):153-173

Gillanders BM, Kingsford MJ (1996) Elements in otoliths may elucidate the contribution of estuarine recruitment to sustaining coastal reef populations of a temperate reef fish. Mar Ecol Prog Ser 141:13-20

Gillanders BM, Able KW, Brown JA, Eggleston DB, Sheridan PF (2003) Evidence of connectivity between juvenile and adult habitats for mobile marine faunas: an important component of nurseries. Mar Ecol Prog Ser 247:281-295

Gray CA, McElligott DJ, Chick RC (1996) Intra- and interestuary differences in assemblages of fishes associated with shallow seagrass and bare sand. Mar Freshw Res 47: 723-735

Gray CA, Chick RC, McElligott DJ (1998) Diel changes in assemblages of fishes associated with shallow seagrass and bare sand. Estuar Coast Shelf Sci 46:849-859

Guidetti P, Bussoti S (2000) Temporal dynamics of Zostera marina L. off the Lagoon of Grado (Northern Adriatic Sea, Italy). Bot Mar 43(6):541-546

Gurevitch J, Hedges LV (2001) Meta-analysis: combining the results of independent experiments. In: Scheiner SM, Gurevitch J (eds) Design and analysis of ecological experiments, 2nd edn. Oxford University Press, New York, p 347-370

Gurevitch J, Morrow LV, Wallace A, Walsh JA (1992) A metaanalysis of field experiments on competition. Am Nat 140: 539-572

Hall MO, Durako MJ, Fourqurean JW, Zieman JC (1999) Decadal changes in seagrass distribution and abundance in Florida Bay. Estuaries 22:445-459

Halliday IA (1995) Influence of natural fluctuations in seagrass cover on commercial prawn nursery grounds in a subtropical estuary. Mar Freshw Res 46:1121-1126

Hanekom N, Baird D (1984) Fish community structures in Zostera and non-Zostera regions of the Kromme Estuary, St. Francis Bay. S Afr J Zool 19(4):295-301

Haywood MDE, Vance DJ, Loneragan NR (1995) Seagrass and algal beds as nursery habitats for tiger prawns 
(Penaeus semisulcatus and P. esculentus) in a tropical Australian estuary. Mar Biol 122:213-223

Heck KL, Crowder LB (1991) Habitat structure and predatorprey interaction in vegetated aquatic systems. In: Bell SS, McCoy ED, Mushinsky HR (eds) Habitat complexity: the physical arrangement of objects in space. Chapman \& Hall, New York, p 281-299

Heck KL, Valentine JF (1995) Sea urchin herbivory: evidence for long lasting effects in subtropical seagrass meadows. J Exp Mar Biol Ecol 189:205-217

Heck KL, Wilson KA (1987) Predation rates on decapod crustaceans in latitudinally separated seagrass communities: a study of spatial and temporal variation using tethering techniques. J Exp Mar Biol Ecol 197:87-100

Heck KL, Able KW, Fahay MP, Roman CT (1989) Fishes and decapod crustaceans of Cape Cod eelgrass meadows: species composition, seasonal abundance patterns and comparison with unvegetated substrates. Estuaries 12:59-65

Heck KL, Nadeau DA, Thomas R (1997) The nursery role of seagrass beds. Gulf Mex Sci 1:50-54

Hedges LV, Olkin I (1985) Statistical methods for metaanalysis. Academic Press, New York

Holt SA, Kitting CL, Arnold CR (1983) Distribution of young red drums among different sea-grass meadows. Trans Am Fish Soc 112:267-271

Howe JC, Wallace RK (2000) Relative abundance of postlarval and juvenile Penaeid shrimps in submerged aquatic vegetation and emergent marsh habitats. Gulf Mex Sci 18: 130-137

Hyndes GA, Potter ICR, Lenanton CJ (1986) Habitat partitioning by whiting species (Sillaginidae) in coastal waters. Environ Biol Fish 45:21-40

Jenkins GP, Sutherland CR (1997) The influence of habitat structure on nearshore fish assemblages in a southern Australian embayment: colonisation and turnover rate of fishes associated with artificial macrophyte beds of varying physical structure. J Exp Mar Biol Ecol 218:103-125

Jenkins GP, Wheatly MJ (1998) The influence of habitat structure on nearshore fish assemblages in a southern Australian embayment: comparison of shallow seagrass, reef-algal, and unvegetated sand habitats, with emphasis on their importance to recruitment. J Exp Mar Biol Ecol 221:147-172

Jordan F, Bartolini M, Nelson C, Patterson PE, Soulen HL (1996) Risk of predation affects habitat selection by the pinfish Lagodon rhomboides (Linnaeus). J Exp Mar Biol Ecol 208:45-56

Kenyon RA, Loneragan NR, Hughes J, Staples DJ (1997) Habitat type influences the microhabitat preference of juvenile tiger prawns (Penaeus esculentus Haswell and Penaeus semisulcatus De Haan). Estuar Coast Shelf Sci 45:393-403

Kenyon RA, Haywood MDE, Heales DS, Loneragan NR, Pendrey RC, Vance DJ (1999) Abundance of fish and crustacean postlarvae on portable artificial seagrass units: daily sampling provides quantitative estimates of the settlement of new recruits. J Exp Mar Biol Ecol 232:197-216

Laprise R, Blaber SJM (1992) Predation by Moses perch, Lutjanus russelli, and blue-spotted trevally, Caranx bucculentus, on juvenile brown tiger prawn, Penaeus esculentus: effects of habitat structure and time of day. J Fish Biol 40: $627-635$

Leber KM (1985) The influence of predatory decapods, refuge, and microhabitat selection on seagrass communities. Ecology 66:1951-1964

Levin P, Petrik R, Malone J (1997) Interactive effects of habitat selection, food supply and predation on recruitment of an estuarine fish. Oecologia 112(1):55-63

Lipcius RN, van Engel WA (1990) Blue crab population dy- namics in Chesapeake Bay: variation in abundance (York River, 1972-1988) and stock recruit functions. Bull Mar Sci 46:180-194

Loneragan NR, Kenyon RA, Staples DJ, Poiner IR, Conacher CA (1998) The influence of seagrass type on the distribution and abundance of postlarval and juvenile tiger prawns (Penaeus esculentus and P. semisulcatus) in the western Gulf of Carpentaria, Australia. J Exp Mar Biol Ecol 228:175-195

Main KL (1987) Predator avoidance in seagrass meadows: prey behavior, microhabitat selection, and cryptic coloration. Ecology 68:170-180

Malloy KD, Yamashita Y, Yamada H, Targett TE (1996) Spatial and temporal patterns of juvenile stone flounder Kareius bicoloratus growth rates during and after settlement. Mar Ecol Prog Ser 131:49-59

Mattila J (1995) Does habitat complexity give refuge against fish predation? Some evidence from two field experiments. In: Elifeftheriou A, Ansell AD, Smith CJ (eds) Biology and ecology of shallow coastal waters. Olsen \& Olsen, Fredensborg, p 261-268

Mattilla J, Chaplin G, Eilers MR, Heck KL Jr, O'Neil JP, Valentine JF (1996) Spatial and diurnal distribution of invertebrate and fish fauna of a Zostera marina bed and nearby unvegetated sediments in Damariscotta River, Maine (USA). J Sea Res 41:321-332

McMichael RH Jr, Peters KM (1989) Early life history of spotted seatrout, Cynoscion nebulosus (Pisces: Sciaenidae), in Tampa Bay, Florida. Estuaries 12(2):98-110

Morgan SG, Zimmer-Faust RK, Heck KL Jr, Coen LD (1996) Population regulation of blue crabs Callinectes sapidus in the northern Gulf of Mexico: Postlarval supply. Mar Ecol Prog Ser 133:73-88

Nagelkerken I, Dorenbosch M, Verberk WCEP, Cocheret de la Moriniere E, van der Velde G (2000) Importance of shallow-water biotopes of a Caribbean bay for juvenile coral reef fishes: patterns in biotope association, community structure and spatial distribution. Mar Ecol Prog Ser 202: 175-192

Nelson WG (1979) Experimental studies of selective predation on amphipods: consequences for amphipod distribution and abundance. J Exp Mar Biol Ecol 38:225-245

Olmi E, Lipcius R (1991) Predation on post-larvae of the blue crab, Callinectes sapidus Rathbun, by sand shrimp, Crangon septemspinosa Say, and grass shrimp, Palaeomonetes pugio Holthuis. J Exp Mar Biol Ecol 151:169-183

Olney JE, Boehlert GW (1988) Nearshore ichthyoplankton associated with seagrass beds in the lower Chesapeake Bay. Mar Ecol Prog Ser 45:33-43

Orth RJ (1992) A perspective on plant-animal interactions in seagrasses: physical and biological determinants influencing plant and animal abundance In: John DM, Hawkins SJ, Price JH (eds) Plant-animal interactions in the marine benthos. Systematics Assoc Spec Vol 46. Clarendon Press, Oxford, p 147-164

Orth RJ, Moore KA (1983) Chesapeake Bay: an unprecedented decline in submerged aquatic vegetation. Science 222:51-53

Orth RJ, van Montfrans J (1987) Utilization of a seagrass meadow and tidal marsh creek by blue crabs, Callinectes sapidus: seasonal and annual variations in abundance with emphasis on post-settlement juveniles. Mar Ecol Prog Ser 41:283-294

Orth RJ, Heck KL, van Montfrans J (1984) Faunal communities in seagrass beds: a review of the influence of plant structure and prey characteristics on predator-prey relationships. Estuaries 7:339-350 
Orth RJ, van Montfrans J, Lipcius RN, Metcalf KS (1996) Utilization of seagrass habitat by the blue crab, Callinectes sapidus Rathbun, in Chesapeake Bay: a review. In: Kuo J, Phillips RC, Walker DI, Kirkman H (eds) Seagrass biology. Proceedings of an International Workshop, Rottnest Island, Western Australia. Western Australian Museum, Perth, p 213-224

Perkins-Visser E, Wolcott TG, Wolcott DL (1996) Nursery role of seagrass beds: enhanced growth of juvenile blue crabs (Callinectes sapidus). J Exp Mar Biol Ecol 198:155-173

Petersen CGJ, Boysen-Jensen R (1911) Valuation of the sea. Rep Dan Biol Stat 20:3-81

Petrik R, Levin PS, Stunz GW, Malone J (1999) Recruitment of Atlantic croaker, Micropogonias undulatus: Do understanding postsettlement processes disrupt or reinforce initial patterns of settlement? Fish Bull 974:954-961

Phelan BA, Goldberg R, Bejda AJ, Pereira J and 5 others (2000) Estuarine and habitat-related differences in growth rates of young-of-the-year winter flounder (Pseudopleuronectes americanus) and tautog (Tautoga onitis) in three northeastern US estuaries. J Exp Mar Biol Ecol 247:1-28

Pile AJ, Lipcius RN, van Montfrans J, Orth RJ (1996) Densitydependent settler-recruit-juvenile relationships in blue crabs. Ecol Monogr 66:277-300

Raposa KB, Oviatt CA (2000) The influence of contiguous shoreline type, distance from shore, and vegetation biomass on nekton community structure in eelgrass beds. Estuaries 23:46-55

Rasmussen E (1977) The wasting disease of eelgrass (Zostera marina) and its effects on environmental factors and fauna. In: McRoy CP, Helfferich C (eds) Seagrass ecosystems: a scientific perspective. Marcel Dekkel, New York, p 1-51

Ray M, Stoner AW (1995) Growth, survivorship and habitat choice in a newly settled seagrass gastropod, Strombus gigas. Mar Ecol Prog Ser 123:83-94

Robblee MB, Barber TR, Carlson PR, Durako MJ and 6 others (1991) Mass mortality of the tropical seagrass Thalassia testudinum in Florida Bay (USA). Mar Ecol Prog Ser 71:297-299

Robertson AI, Duke NC (1987) Mangroves as nursery sites: comparisons of the abundance and species composition of fish and crustaceans in mangroves and other nearshore habitats in tropical Australia. Mar Biol 96:193-205

Rooker JR, Holt GJ, Holt SA (1997) Condition of larval and juvenile red drum Sciaenops ocellatus from estuarine nursery habitats. Mar Biol 127:387-394

Rooker JR, Holt GJ, Holt SA (1998) Vulnerability of newly settled red drum Sciaenops ocellatus to predatory fish: Is early-life survival enhanced by seagrass meadows? Mar Biol 131:145-151

Rosenberg MS, Adams DC, Gurevitch J (2000) MetaWin. Statistical software for meta-analysis. Version 2.0. Sinauer Associates, Sutherland, MA

Rozas LP, Minello TJ (1998) Nekton use of salt marsh, seagrass, and nonvegetated habitats in a south Texas (USA) estuary. Bull Mar Sci 63(3):481-501

Ryer CH (1987) Temporal patterns of feeding by blue crabs (Callinectes sapidus) in a tidal-marsh creek and adjacent seagrass meadow in the lower Chesapeake Bay. Estuaries 10:136-140

Ryer CH, van Montfrans J, Moody KE (1997) Cannibalism, refugia and the molting blue crab. Mar Ecol Prog Ser 147:77-85

Schoener TW (1983) Field experiments on interspecific competition. Am Nat 122:240-285

Sedberry GR, Carter J (1993) The fish community of a shallow tropical lagoon in Belize, Central America. Estuaries 16(2): 198-215

Sheridan P (1997) Benthos of adjacent mangrove, seagrass and non-vegetated habitats in Rookery Bay, Florida (USA). Estuar Coast Shelf Sci 44:455-469

Short FT, Wyllie-Echeverria S (1996) Natural and humaninduced disturbance of seagrasses. Environ Conserv 23: $17-27$

Sih A, Crowley P, McPeek M, Petranka J, Strohmeier K (1985) Predation, competition, and prey communities: a review of field experiments. Annu Rev Ecol Syst 16:269-311

Sogard SM (1992) Variability in growth rates of juvenile fishes in different estuarine habitats. Mar Ecol Prog Ser 85:35-53

Stoner AW (1982) The influence of benthic macrophytes on the foraging behavior of pinfish, Lagodon rhomboides. J Exp Mar Biol Ecol 58:271-284

Stoner AW, Sandt VJ (1991) Experimental analysis of habitat quality for juvenile Queen conch in seagrass meadows. Fish Bull 89(4):693-700

Stoner AW, Waite JM (1990) Distribution and behavior of queen conch Strombus gigas relative to seagrass standing crop. Fish Bull 88(3):573-585

Stoner AW, Ray M, Glazer RA, McCarthy KJ (1996) Metamorphic responses to natural substrata in a gastropod larva: decisions related to postlarval growth and habitat preference. J Exp Mar Biol Ecol 205:229-243

Swart PK, Healy G, Greer L, Lutz M, Saied A, Anderegg D, Dodge RE, Rudnick D (1999) The use of proxy chemical records in coral skeletons to ascertain past environmental conditions in Florida Bay. Estuaries 22:384-397

Thomas JL, Zimmerman RJ, Minello TJ (1990) Abundance patterns of juvenile blue crabs (Callinectes sapidus) in nursery habitats of two Texas bays. Bull Mar Sci 46:115-125

Tolan JM, Holt SA, Onuf CP (1997) Distribution and community structure of ichthyoplankton in Laguna Madre seagrass meadows: potential impact of seagrass species change. Estuaries 20(2):450-464

Tupper M, Boutilier RG (1995) Effects of habitat on settlement, growth, and postsettlement survival of Atlantic cod (Gadus morhua). Can J Fish Aquat Sci 52:1834-1841

Valentine J, Heck KL (1993) Mussels in seagrass meadows: their influence on macroinvertebrate abundance and secondary production in the northern Gulf of Mexico. Mar Ecol Prog Ser 96:63-74

Weinstein MP, Brooks HA (1983) Comparative ecology of nekton residing in a tidal creek and adjacent seagrass meadow: community composition and structure. Mar Ecol Prog Ser 12:15-27

Williams AH, Cohen LD, Stoelting MS (1990) Seasonal abundance, distribution and habitat selection of juvenile Callinectes sapidus Rathbun in the northern Gulf of Mexico. J Exp Mar Biol Ecol 137:165-183

Williams SW, Heck KL Jr (2001). Seagrass communities. In: Bertness MM, Gaines S, Hay M (eds) Marine community ecology. Sinauer Press, Sunderland, MA, p 317-337

Wilson KA, Heck KL Jr, Able KW (1987) Juvenile blue crab, Callinectes sapidus, survival: an evaluation of eelgrass, Zostera marina, as refuge. Fish Bull 85:53-58

Wilson KA, Able KW, Heck KL (1990) Predation rates on juvenile blue crabs in estuarine nursery habitats: evidence for the importance of macroalgae (Ulva lactuca). Mar Ecol Prog Ser 58:243-251

Worthington DG, Westoby M, Bell JD (1991) Fish larvae settling in seagrass: effects of leaf density and epiphytic algae. Aust J Ecol 16:289-293

Young PC (1978) Moreton Bay, Queensland: a nursery area for juvenile penaeid prawns. Aust J Mar Freshw Res 29:55-75

Young PC, Carpenter SM (1977) Recruitment of postlarval penaeid prawns to nursery areas in Moreton Bay, Queensland. Aust J Mar Freshw Res 28:745-773 